\title{
The Protective Effect of Vitamin E against Genotoxicity of Lead Acetate Intraperitoneal Administration in Male Rat
}

\author{
Nadia AIT HAMADOUCHE ${ }^{* 1}$, Nesrine SADI', Omar KHAROUBI ${ }^{1}$ \\ Miloud SLIMANI², Abderlkader AOUES' \\ ${ }^{1}$ Department of Biology, Laboratory of Experimental Biotoxicology, Biodepollution and \\ Phytoremediation,Dr Moulay TaharOran, Algeria; naithamadouche@live.fr \\ ${ }^{2}$ Department of Biology, Faculty of Science and Technology, Saida, Algeria
}

\begin{abstract}
Lead is industrial pollutant that may have toxic effects on the male. The aim of this study was to further investigate the protective effects of vitamin $\mathrm{E}$ on lead acetate $(\mathrm{Pb})$ induced reproductive toxicities and genotoxicity effects in male rat. Sexually mature male Wistar rats (weighing 120-160 g) were given $\mathrm{Pb}(20 \mathrm{mg} / \mathrm{Kg})$ and vitamin E $(600 \mathrm{mg} / \mathrm{kg} / \mathrm{rat})$ orally for 20 days. The sperm counts, sperm motility, sperm morphology, chromosomal aberrations, FSH, LH and testosterone levels, and histopathological changes in the testes of these rats, were investigated at the end of 20 days. Result revealed a statistically significant $(\mathrm{p}<0.01)$ increase in the number of abnormal sperm in treated animal. Lead acetate increased the percentage of chromosomal abnormalities. Significant decrease in LH, FSH, and testosterone were observed in treated group compare with the control. Pathological examination of testicular tissues showed degenerative changes of spermatogonia and spermatocytes to advanced degeneration and vacuolation. The observation, dealing that lead acetate can be considered as an environmental genotoxic and cytotoxic effect in male rat and may contribute in reduction of fertility. We recommended that it must be administered of vitamin $\mathrm{E}$ as a protective agent to reduce the genotoxic effect of lead in the somatic and germ cells.
\end{abstract}

Keywords: lead, genotoxicity, chromosome aberration, vitamin E

\section{Introduction}

The humans are exposed to various types of environmental contaminants at different stages of their life span, majority of them are harmful. In recent years, there has been growing concern about the deleterious effects of chemical on developing male reproductive system. Exposure of heavy metals during pregnancy has been associated with adverse effects on development of gonads. These substances may act as testicular toxicants and correspond to different compounds, which are related to social habits, life conditions, working hazards or use of drugs and medicines (Johnson et al., 1970; Pomerol and Arrondo, 1994; Bustos-Obregón, 2001). Although, many studies have reported the toxic and carcinogenic effects of metals in human and animals, it is also well known that these metals form a crucial part innormal biological functioning of cells. Many heavy metals are classical testicular toxicants, though the mechanism of their action may differ. Lead is a male reproductive toxicant (Winder, 1989), the primary mechanism of the toxic action of lead appears to be a disruption of the hypothalamic control of pituitary hormone secretion and in turn, spermatogenesis (Sokol, 1987). Since male do not possess accessory reproductive organs, reproductive potential relates to three factors: sperm availability, quality and quantity (Tsuji and Karagatzides,
2001). Vitamins are essential to maintain normal metabolic processes and homeostasis within the body. Vitamin $\mathrm{C}$ (Vit $\mathrm{C}$ ) and vitamin $\mathrm{E}$ (Vit E) are low molecular mass antioxidants that scavenge or quench free radicals (Janisch et al., 2005). Reactive oxygen species (ROS) related lead toxicity in the rat sperm was prevented by Vit $\mathrm{C}$ or Vit E (Hsu et al., 1998). These findings suggest potential role of antioxidants to ameliorate lead toxicity. The natural antioxidants may be helpful in preventing or reducing the harmful effects of ROS on testes and semen quality (Yousef, 2010). Vitamin E is the main component of the antioxidant system of the spermatozoa and is one of the major membrane protectants against ROS and lipid peroxidation (Akiyama, 1999). Supplemental Vit E increases total sperm output and sperm concentration in rabbits (Yousef, 2010) and rams (Yue et al., 2010). Conversely, deficiency of Vit $\mathrm{E}$ may lead to detrimental effects on the reproductive organs, such as degenerative spermatogonium, testicular damage and degeneration of the seminiferous tubules (Wilson et al., 2003). Influence of dietary Vit $\mathrm{E}$ on semen quality has been described in mice (SánchezGutiérrez et al., 2008), rat (Wu et al., 1979), rabbit (Cesare et al., 2002) and goats (Shi et al., 2010).

Consequently, this study aimed to evaluate (1) the influence of lead acetate on reproductive organs and fertil- 
ity of male albino rats (2) the protective role of Vit E in alleviating the detrimental effect of lead on male fertility.

\section{Materials and methods}

Thirty adult male Wistar rats (120-160 g) were used for this study. Rats were housed in temperature controlled rooms $\left(25^{\circ} \mathrm{C}\right)$ with constant humidity $(40-70 \%)$ and $12 / 12 \mathrm{~h}$ light/dark cycle prior to use in experimental protocols. All the procedure performed on animals were approved and conducted in accordance with the National Institute of health Guide (Reg. No. 488/160/1999/CPCSEA).

\section{Grouping of animals and treatment}

The rats were grouped into 3 groups (groups A, B, and $C, n=10)$. Animals in group A served as the control group and were drinking distilled water. Animals in groups $\mathrm{B}$ and $\mathrm{C}$ received $20 \mathrm{mg} / \mathrm{Kg}$ by intraperitoneal injections of lead acetate $(\mathrm{Pb})$. Group $\mathrm{C}$ animals were treated with $600 \mathrm{mg} / \mathrm{kg} / \mathrm{rat}$ orally of vitamin E for 20 days. Each rat was weighed every week.

\section{Reproductive organs weights}

All rats were euthanized at the end of the experiment. After animal dissection, the testes, epididymes and accessory sex organs (seminal vesicles and prostate glands) were removed, grossly examined and weighed. The index weight (I.W.) of each organ was calculated by Matousek (1969) I.W. = organ weight $(\mathrm{g}) / 100 \times$ body weight $(\mathrm{g})$.

\section{Sperm motility}

Sperm-progressive motility was evaluated microscopically within $2-4$ min of their isolation from the cauda epididymis as described by Sönmez et al. (2005). Fluid was obtained from the cauda epididymis with a pipette and diluted to $2 \mathrm{ml}$ with tris buffer solution. The percentage of motility was evaluated at $\times 400$ magni-fication.

\section{Sperm abnormalities}

A total of 300 sperm was counted on each slide under light microscope at $\times 400$ magnification and the percentages of morphologically abnormal spermatozoa (detached head and coiled tail) were recorded according to Evans and Maxwell (1987). Smears for sperm morphology were prepared and stained with eosin according to Mukherjee et al. (1988). One thousand sperms were counted for each animal and the abnormal shape involving the head was recorded.

\section{Determination of serum testosterone, $\mathrm{LH}$ and FSH} levels

Blood was collected from abdominal vein of all anesthetized rats before scarification. Serum was separated for assessment of the total serum using electrochemilumineescence immunoassay (ECLIA).
Chromosomal abnormalities in rat bone-marrow cells

After $24 \mathrm{~h}$ from the last treatment, rats were injected with $0.6 \mathrm{mg} \mathrm{kg}^{-1}$ b.w. colcemid $2 \mathrm{~h}$ prior scarification. Bone marrow preparations were prepared according to the method of Preston et al. (1987). Four rats were used for each dosage, where the structural alterations of chromosomes were evaluated in 75 metaphases per animal.

\section{Histological slides preparation}

Specimens from testicular tissues were fixed in 10\% neutral buffer formalin, dehydrated in ascending grades of ethanol alcohols, cleared in xylol, casted, blocked, cut at 2-5 $\mu \mathrm{m}$ thickness and stained with hematoxylin-eosin for microscopic examination (Bancroft, 1975).

\section{Statistical analyis}

All data obtained from control and lead-poisoned animals were compared using student's t-test for unpaired means. A p value $<0,05$ was considered significant.

\section{Results}

\section{Body weight changes}

Tab. 1 shows that rats in control group had significant $(\mathrm{P}<0.05)$ increase in weight. Both lead acetate group lost weight when compared with their initial weights. However the weight loss by the $\mathrm{Pb}$ rats that received vitamin $\mathrm{E}$.

Tab. 1. Effect of lead and its combination with Vit $\mathrm{E}$ on body weight and reproductive organs weights of male rats $(\mathrm{g})$

\begin{tabular}{|cccc|}
\hline $\begin{array}{c}\text { Initial body } \\
\text { weight }\end{array}$ & $170 \pm 1.5$ & $171 \pm 2$ & $170 \pm 2$ \\
\hline $\begin{array}{c}\text { Final body } \\
\text { weight }\end{array}$ & $195 \pm 3$ & $155 \pm 2.5$ & $183 . \pm 1.5$ \\
\hline $\begin{array}{c}\text { I.W. of testes } \\
\text { I.W. of } \\
\text { epididymis } \\
\text { I.W. of }\end{array}$ & $1.60 \pm 0.02$ & $1.24 \pm 0.06^{*}$ & $1.48 \pm 0.04^{*}$ \\
$\begin{array}{c}\text { Accessory } \\
\text { gland }\end{array}$ & $0.91 \pm 0.03$ & $0.68 \pm 0.02^{*}$ & $0.79 \pm 0.03^{*}$ \\
\hline
\end{tabular}

The values expressed as mean \pm SEM $(\mathrm{n}=10) .{ }^{*} \mathrm{P}<0.05$

\section{Organs weights}

The index weight of testis, epididymis and accessory sex glands was significantly decreased $(P \leq 0.05)$ in rats treated with lead compared to the control group. While the reduction was less pronounced in the group treated with lead plus vit. E (Tab. 1).

\section{Differential sperm characteristics}


414

Epididymal sperm concentration, sperm motility, viability and abnormal sperm are reported in Tab. 2 for $\mathrm{Pb}$ and vit. E groups. $\mathrm{Pb}$ group had highly significantly $(\mathrm{p}<0$, $01)$ lower sperm count, motility and viability than the control group. However, vit. E group significantly increased the sperm concentration $(p<0,05)$, when compared to the control group.

Tab. 2. Effect of Vit E on sperm character of lead acetate intoxicated male rats

\begin{tabular}{ccccc}
\hline \multicolumn{5}{c}{ Sperm character } \\
$\begin{array}{c}\text { Experime- } \\
\text { ntal } \\
\text { groups }\end{array}$ & $\begin{array}{c}\text { Count } \\
(106 / \mathrm{ml})\end{array}$ & $\begin{array}{c}\text { Motility } \\
(\%)\end{array}$ & $\begin{array}{c}\text { Viability } \\
(\%)\end{array}$ & $\begin{array}{c}\text { Sperm } \\
\text { abnorm- } \\
\text { alities }(\%)\end{array}$ \\
$\mathrm{Control}$ & $63,3 \pm 3,63$ & $84,4 \pm 4,53$ & $90,6 \pm 4,31$ & $-6,8 \pm 0,51$ \\
$\mathrm{~Pb}$ & $29,6 \pm 1,29^{* *}$ & $43,1 \pm 3,73^{* *}$ & $53,1 \pm 3,65^{* *}$ & $19,4 \pm 0,93^{* *}$ \\
$\mathrm{~Pb}+\mathrm{Vit} \mathrm{E}$ & $45,3 \pm 3,22^{*}$ & $59,4 \pm 2,16^{*}$ & $69,8 \pm 2,85^{*}$ & $13,2 \pm 0,85^{*}$ \\
\hline
\end{tabular}

Tab. 3 and Fig. 1, represented the incidence of abnormality in the shape of sperms per 1000 for each rats treated with $\mathrm{Pb}$ and protected with vit. $\mathrm{E}$, which include hammer shape. 1(Fig a), banana shape (Fig. 1b), lack of hook (Fig. 1c) and amorphous (Fig.1d). The highest incidence of abnormality in the shape of sperms of rats treated with lead acetate was amorphous while hammer shape was the lowest frequency. Vit $\mathrm{E}$ made a high protective role against sperm head abnormalities induced by $\mathrm{Pb}$.
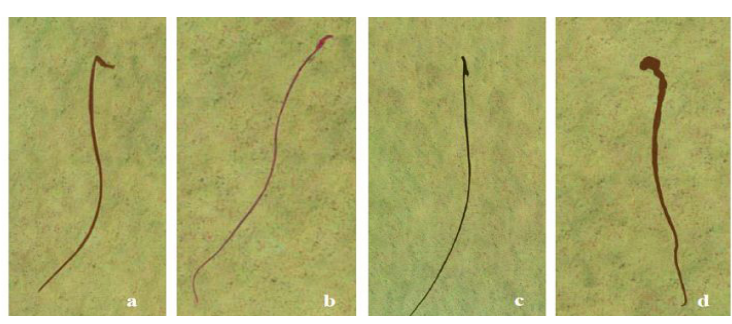

Fig 1. Types of sperm head abnormalities in rat treatment with $\mathrm{Pb}$. a: hammer; b: banana like; c: lake of hook; d: amorphous

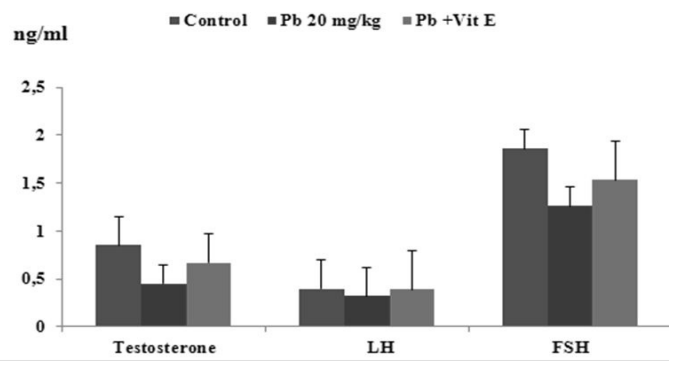

Fig. 2. Serum levels of testosterone, LH and FSH after intraperitoneal lead acetate. The values expressed as $m$ ean \pm SEM $(\mathrm{n}=10) .{ }^{*} \mathrm{p} 0,05^{* *} ; \mathrm{p}<0,01$

\section{Plasma testosterone, $L H$ and FSH level}

Results in Fig. 2 showed highly significant decrease in serum testosterone, $\mathrm{LH}$ and FSH concentration $(\mathrm{p}<0,01)$ in $\mathrm{Pb}$ group compared to control group, while orally treatment with Vit E induced a significant elevation in serum testosterone, $\mathrm{LH}$ and FSH concentration.

Tab. 3. Incidence of the sperm head abnormality per thousand after treatment with $\mathrm{Pb}$ and protection with vit. $\mathrm{E}$

\begin{tabular}{ccccc} 
Groups & \multicolumn{4}{c}{ Abnormal sperm } \\
\cline { 2 - 5 } Control & $11,6 \pm 0,91$ & $1,6 \pm 0,42$ & $2,4 \pm 0,37$ & $0,3 \pm 0,2$ \\
$\mathrm{~Pb} 20$ & $42,4 \pm 0,86^{* *}$ & $17,8 \pm 0,51^{* *}$ & $15,8 \pm 0,70^{* *}$ & $2,4 \pm 0,51^{* *}$ \\
$\mathrm{mg} / \mathrm{kg}$ & $\mathrm{h}$ hook & $\begin{array}{c}\text { Hummer } \\
\text { shape }\end{array}$ \\
\hline $\mathrm{Pb}+\mathrm{Vit} \mathrm{E}$ & $18,4 \pm 0,67^{*}$ & $3,8 \pm 0,35^{*}$ & $2,4 \pm 0,4^{*}$ & $0,9 \pm 0,24^{*}$ \\
\hline
\end{tabular}

Chromosomal abnormalities in rat bone-marrow cells

Various chromosomal aberration are observed in the bone marrow cells of male treated with $\mathrm{Pb}$ and protected with Vit E. Structural and numerical types of aberration are elucidate in Tab. 4 and Fig. 3 respectively. Tab. 4 , showed the average of chromosomal abnormalities of bone marrow cells of male rats treated with $\mathrm{Pb}$ and protected with Vit E.
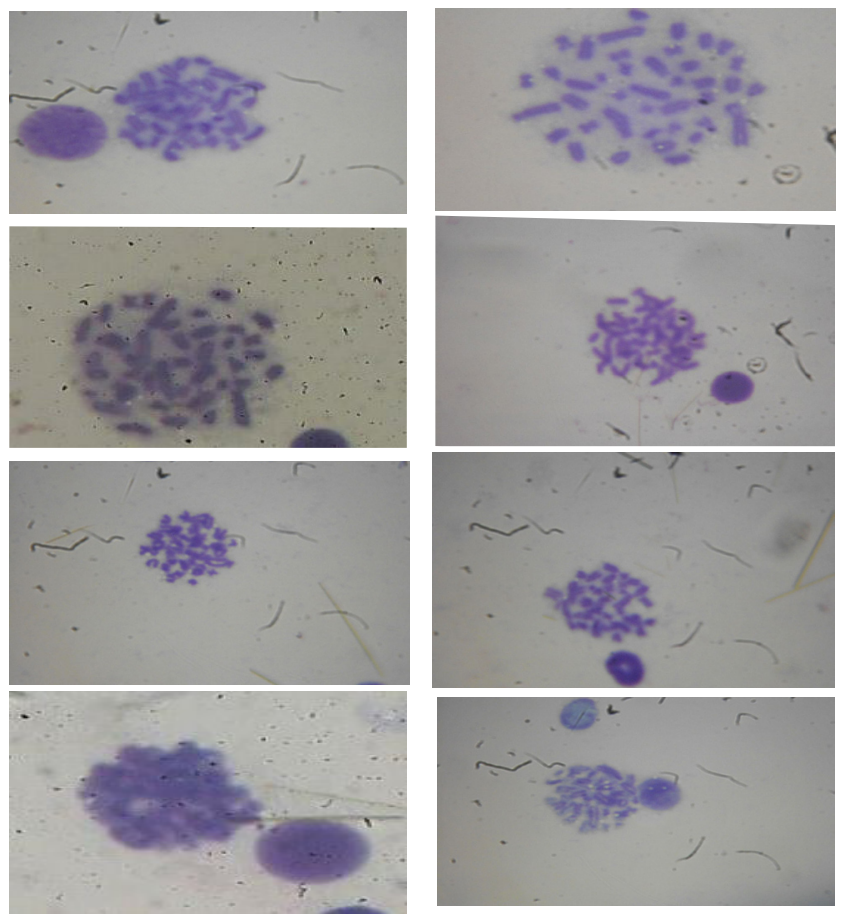

Fig. 3. Types of chromosomal aberrations in rat bone marrow cells treared with acetate lead.a: control; b: centromeric attenuation (Cat) and fusion (Fu); c: Fusion (Fu); d: chromasomal ring (R); e: centromeric attenuation (Cat); f: chromasomal ring (R) and fusion (F); g: deletion (D), chromasomal ring (R), gap (G); h: sticky chromosome 
It represented a very high significant increase in treated group with $\mathrm{Pb}$ than control group, on the other hand it indicate that vit. $\mathrm{E}$ made a high protective role against $\mathrm{Pb}$. The structural aberrations included chromatid deletion (Fig. 3g), centromeric attenuation (Fig. 1be), centric fusion (Fig 1. cf), gap (Fig .3 g), and chromosomal ring (Fig. 1df). Stickiness may give arise to sticky adhesion between two or more chromosomes, and formation of stick bridges at metaphase (Fig. 3h).

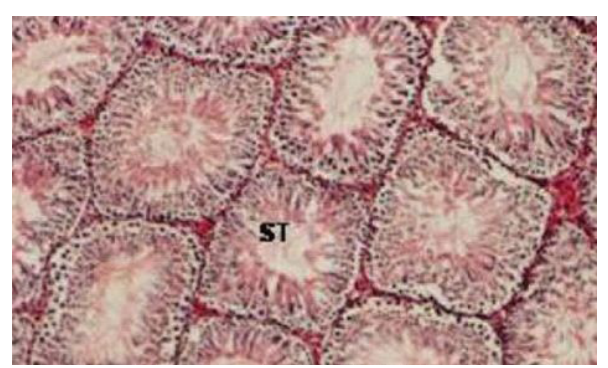

Fig. 4. Testes of male rats control showing normal structure of seminiferous tubules (ST) (H\&E X 200)

Tab. 4. Average of chromosomal abnor malities observed in bone marrow cells of male rats treated with $\mathrm{Pb}$ and protected with Vit E

\begin{tabular}{c|ccccccccc}
\hline \multicolumn{7}{c}{ Structural aberrations } \\
$\begin{array}{c}\text { Gro } \\
\text { ups }\end{array}$ & $\begin{array}{c}\text { Deleti- } \\
\text { on }\end{array}$ & $\begin{array}{c}\text { Chrom- } \\
\text { atid } \\
\text { fragme- } \\
\text { nts }\end{array}$ & Ring & $\begin{array}{c}\text { Centro- } \\
\text { meric } \\
\text { attenu- } \\
\text { ation }\end{array}$ & $\begin{array}{c}\text { Centric } \\
\text { fusion }\end{array}$ & Breaks & Gaps & Sticky & Total \\
$\begin{array}{c}\text { Contr- } \\
\text { ol }\end{array}$ & $3,2 \pm 0,2$ & $0,98 \pm 0,3$ & $0,78 \pm 0,2$ & $0,6 \pm 0,2$ & $0,4 \pm 0,2$ & $0,4 \pm 0,2$ & $0,5 \pm 0,2$ & $0,7 \pm 0,3$ & $7,56 \pm 1,5$ \\
\hline $\begin{array}{c}\mathrm{Pb} 20 \\
\mathrm{mg} / \\
\mathrm{kg}\end{array}$ & $28,8 \pm 0,8$ & $10,6 \pm 0,3$ & $6,2 \pm 0,3$ & $3,4 \pm 0,6$ & $2,8 \pm 0,4$ & $6,8 \pm 0,3$ & $1,6 \pm 0,4$ & $1,4 \pm 0,5$ & $61,6 \pm 3,6$ \\
\hline $\begin{array}{c}\mathrm{Pb}+\mathrm{Vit} \\
\mathrm{E}\end{array}$ & $14,9 \pm 0,4$ & $5,4 \pm 0,4$ & $2,6 \pm 0,3$ & $1,2 \pm 0,3$ & $1,3 \pm 0,3$ & $1,2 \pm 0,2$ & $0,8 \pm 0,2$ & $0,98 \pm 0,4$ & $28,38 \pm 2,5$ \\
\hline
\end{tabular}

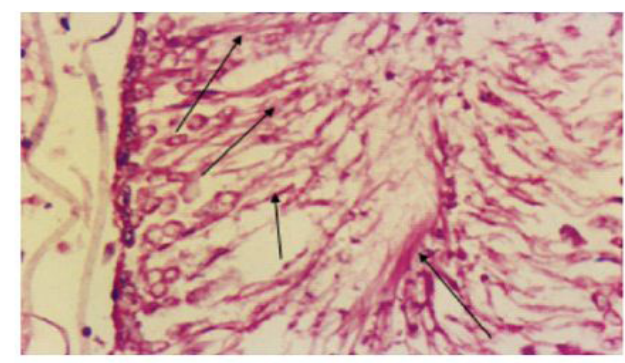

Fig. 7. Testes of male albino rats intoxicated with cadmium chloride alone showing complete testicular necrosis and sloughing of all layers, Ischemic necrosis, (Arrows) (H\&E .X. 400).

Fig. 5. Testes of male rat intoxicated with lead acetate showing complete testicular necrosis and sloughing of all layers, ischemic necrosis (arrows) (H\&E X 400)

\section{Histophatological results}

The normal architecture of testicular seminiferous tubules and interstitial spaces were shown in the control rats (Fig 4). Moreover, in rats witch were intoxicated with lead acetate showed complete necrosis and sloughing of all layers of seminiferous tubules (Fig. 5). The testes of rats, treated with Vit $\mathrm{E}$ showed mild to moderate edema, congestion with minute foci necrosis and hemorrhage (Fig. 6-7).

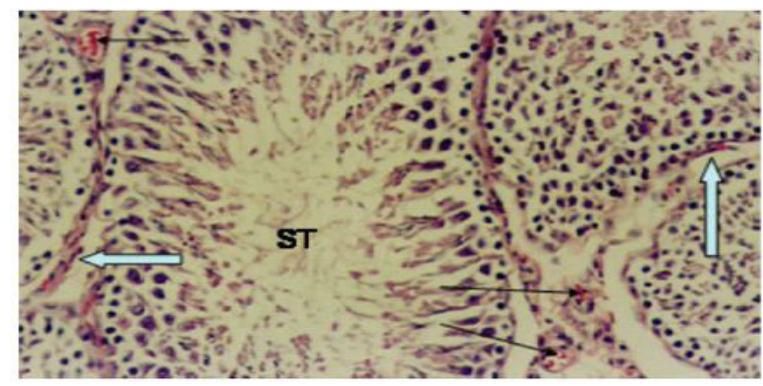

Fig. 6. Testes of male rats treated with lead acetate and vitamin E showing mild degenerative changes of seminiferous tubules (ST), mild congestion (thin arrows) and edema (hollow arrows) (H\&E X 200)

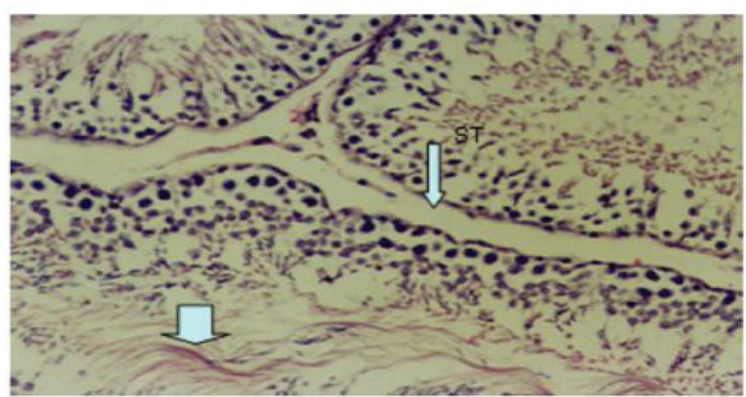

Fig. 7. Testes of male rats treated with lead acetate ant vitamin E showing nearly normal seminiferous tubules with mild odema (thin hollow arrow) and necrosis (big hollow arrow) (H\&e X 200)

\section{Discussion}

The toxicity of lead has been studied from many years throughout several end-points but data related to the mutagenic, clastogenic and carcinogenic properties of lead and lead compounds is still conflicting. The IARC classified lead as possible human carcinogen (IARC, 1987), on the basis of sufficient evidence for carcinogenicity in experimental animals but inadequate evidence for carcinogenicity in humans, and the inorganic lead compounds are classified as probable human carcinogens (IARC, 2006), on the basis of sufficient evidence for carcinogenicity in experimental animals but limited evidence for carcinogenicity in humans. However, in those studies that evaluated the induction of chromosomes aberration by lead chromate (Douglas et al., 1980; Wise et al., 2003; Wise et al., 2004; Xie et al., 2005), the positive results achieved may be related to the toxic action of chromate and no to lead, based on the results reported by Douglas et al. (1980). The variability found in the different studies could be due to 
416

the influence of different experimental variables that may act as confounding factors, such as duration route of lead exposure, cell culturing time following the exposure, smoking habits and simultaneous exposure to other toxic agents that could act by modifying the genotoxic response of the cells to lead exposure and similarly, modifying the results of the studies. Redarding to this last factor, many of the epidemiological studies reviewed suggest the possibility that multiple exposures present in the occupational environment, and not only lead, are responsible for the obtained results (Garcì-Lestòn et al., 2010). To our knowledge, the present study planned to evaluates the protective effect of vitamin $\mathrm{E}$ against testicular damage induced by lead acetate toxicity in experimental animals. The effect of lead acetate on final body weight of intoxicated rats was significantly lower than that of the health normal group. These results clearly indicated that lead caused a significant decrease in the gain of body weight. Nabil et al. (2012) found that lead caused decrease in growth rate in rats when fed lead. These results in body weight gain which may be caused by the toxic ions could be associated with several factors, one of which is imbalance metabolism produced by impairing zinc status in zinc-dependent enzymes which are necessary for many metabolic processes. Along with the decrease in body weight, a significant reduction in testicular weight was also found in lead acetate treated animals. Weight of the testis is largely dependent on the mass of the differentiated spermatogenic cells. Hence a reduction in its weight might be due to the decreased number of germ cells and elongated spermatids (Chapin et al., 1997). Weight of accessory sex organs were also decreased in lead acetate treatment. Weight loss of accessory sex organs corresponds with the decrease in serum testosterone concentration as observed in this study. It has been reported that testosterone plays a major role in the maintenance of structural integrity and functional activities of the accessory sex organs (Moor et al., 1930a).

As mentioned earlier, in the present study serum testosterone level $\mathrm{LH}$ and FSH were decreased in lead acetate treated groups of animals as compared to their respective control. Significant alterations in testostrone LH and FSH levels have been reported after exposure to certain heavy metals (Gabuchyan, 1987; Chattopadhyay et al., 2005; Atef Al Attar, 2011). LH and FSH activity depends on both the quantity of these hormones and the number of specific receptors in the testis. It has been shown that exposure to environmental contaminants adversely affects testicular function by decreasing pituitary $\mathrm{LH}$ secretion and reducing Leydig cell steroidogenesis (Akingbemi et al., 2004; Murugesan et al., 2007). Together with gonadotrophins, testosterone is a keyhormone that regulates spermatogenesis. The secretion of testosterone by the Leydig cells is dependent upon the secretion of LH by the pituitary gland (Fatma Gokce Uzun et al., 2009). This may be because lead induces pathological change in the Leydig cells in the interstitial tissues. In our study, the FSH and
LH levels in lead acetate-treated rats were significantly lower than the levels in the control rats at the end of the 20 days. To Notably, however, treatment with vitamin $\mathrm{E}$ has a protective effect on FSH and LH levels. These results may be explained by the androgenic activities of vitamin $\mathrm{E}$, this activity was reflected by the increase of testis weight and serum testosterone, LH and FSH levels (Muthu and Krishnamoothy, 2012). The potential toxicity of lead caused alterations in sperm morphology, count, motility as well as hormones (Chowdhury, 2009). Lead has an adverse effect on sperm count and retarted the activity of alive sperm. Morever, motility as well as prolonged latency of sperm melting both in exposed person and experimental animals were observed after $\mathrm{Pb}$ exposure (Lancranjan et al., 1975; Chowdhury et al., 1986). In the present study a significant decrease in the total sperm number was found in lead acetate-treated rats compared to control. Lead was reported to induce apoptosis in the testis (NavaHernandez et al., 2009). Moreover, the decrease motility and increased incidence of teratospermia at higher dose of $\mathrm{Pb}$ exposure along with inhibition of post-meiotic cells mainly pachytene spermatocyte were noted (Attar, 2011). In the same experiment the detachment of germinal cell layer from basal membrane, atrophy of leydig cells plus interstisial edema and low density of seminal plasma were also observed. Additionally, Madhavi et al. (2007) showed that $\mathrm{Pb}$ induced cytogenetic damage in germ cells of mice. Testicular damage xas also confirmed by histopathological lesions (Muthu and Krishnamoothy, 2012). The present study clearly demonstrated that lead acetate can seriously alter the testicular tissues which started the changes with vacuolar degeneration till necrosis and atrophy of semineferous tubules. Treated groups showing vacuolation and degenerative changes of most spermatogonia arrest of spermatogenesis and pyknotic changes of spermatocytes. The center of most seminiferous tubules showed moderated number of spermatozoa and edema, advenced degeneration and necrisis of spermatogonia and interstitial cells and abnormal distribution of spermatozoa. These results indicating that in male rats, lead targets testicular spermatogenesis and sperm within the epididymis to produce reproductive toxicity. These findings support the results from other reports that lead acetate can seriously alter the testes and reproductive tract in mal rats treatedwith lead (Johansson and Pellicciari, 1988; El-Shafai et al., 2011). However, little is known about vitamin $\mathrm{E}$ act as protective agents against lead induced testicular toxicity. Administration of vitamin $\mathrm{E}$ with $\mathrm{Pb}$ treatment clearly restored the testicular damage. Accumulating evidence suggest that the protective effect of vitamin E could be attributed to its anti-oxidative properties (Wang et al., 2004). From our results of the induction of chromosomal aberrations in bone marrow cells of rat treated with lead acetate, the aberrant type induced was only the structural type (chromatid gaps, deletion and fragment). It was clearly indicated that gaps are the most frequent type of aberration to be 
induced by lead exposure as mentioned by Nordenson $e t$ al. (1978). In the present study, $\mathrm{Pb}$ increase in percentage of chromosome abnormalities in spermatocytes and sperm head abnormalities induced lead emphasize the positive correlation between cytogenetic damage and sperm abnormality which was previously reported in mice (Lavu et al., 1985; El-Nahas et al., 1989). A significant increase in the percentage of spoerm abnormalities occurred with lead acetate treated animals. It may be mentioned in this context that, increase in the incidence of abnormal sperm have been reported after treatment of male mice with irradiation (Wyrobek and Bruce, 1978) as well as different chemical agents (insecticide) (Hassan et al., 1995). In the present stydy, the sperm head abnormalities as amorphous and banana like was the highest incidence of aberration in treated group, while lack of hook and hammer shape was the lowest frequency. This study showed that rats treated with lead acetate revealed an increase in the frequency of total epididymal sperm head abnormalities. These results in accordance with García-Lestòn et al. (2010) who suggest that lead would induce disruption of spermatogenesis in the testes causing detoriation of motility and content of sperm as well as morphological abnormalities. In an atteempt to explain the different mechanisms involved in the induction of the abnormal morphology of the sperm heads. Kaczmarski (1972) stated that incomplete condensation of chromatin and the presence of large vacuoles and canals containing remmants of cytoplasm in various regions of the head is the cause of failure of sperm to pass through the final steps of maturations occurring normally during spermatogenesis. Moreover, Topham (1980a) mentioned the agents which accumulate in the testis can cause alterations in testicular DNA and disrupt the process of differentiation of spermatozoa directly.It is clear from the obtained results that viatim $\mathrm{E}$ made a high protective role against sperm head abnormalities induced by lead acetate.

\section{Conclusion}

In conclusion, the combination of laboratory tests, suggested that lead acetate can be considered as an environmental genotoxic material. Besides, the present study showed that viatmin $\mathrm{E}$ has protective effect on lead acetate induced testiculare damage. This study therefore suggests that vitamin E may be a useful preventive agent against the effect on the studied lead acetate at least partly due to its antioxidant properties.

\section{References}

Akiyama M (1999). In vivo scavenging effect of ethylcysteine on reactive oxygen species in human semen. Nippon Hinyokika Gakkai Zasshi 90(3):421-428.

Atef M Al-Attar (2011). Antioxidant effect of vitamin E treatment on some heavy metals-induced renal and testicular injuries in male mice. Saudi J of Biol Sci 18:63-72.
417

Bancroft JD (1975). Histopathological stains and their diagnostic uses. Edinburgh, New York, Churchill Livingstone.

Bustos-Obregón E (2001). Adverse Effects of exposure to agropesticides on male reproduction. APMIS Denmark 109(103):233-242.

Cesare C, Paolo L, Alessandro DB, Daniela B (2002). Effect of supranutritional level ofdietary -tocopheryl acetate and selenium on rabbit semen. Theriogenology 58:1723-32.

Chapin RE, Harris Davis MW, Ward BJ, Wilson SM, Mauney RE, Lockhart MA, Smialowicz AC, Moser RJ, Burka VC,

Collins BJ (1997). The effects of perinatal/juvenile methoxychlor exposure on adult rat nervous, immune, and reproductive system function. National Toxicology Program, NIEHS, North Carolina, USA. Fundam Appl Toxicol 40(1):138-57.

Chattopadhyay R, Sarkar M, Biswas NM (2005). Dose-dependent effect of copper chloride on male reproductive function in immature rats. Kathmandu Univ Med J 3:392-400.

Chowdhury R (2009). Recent advances in heavy metals induced effect on male reproductive function-A retrospective. $\mathrm{Al}$ Ameen J. Med. Sci 2:37-42.

Chowdhury A, Rao RV, Gautam AK (1986). Histochemical changes in the testes of lead induced experimental rats. Folia Histochem Cytobiol 24:233-238.

Dougla GR, Bell RD, Grant CE, Wytsma JM, Bora KC (1980). Effect of lead chromate on chromosome aberration, sisterchromatid exchange and DNA damage in mammalian cells in vitro. Mutat Res 77:157-63.

El-Shafai A, Zohdy N, El-Mulla KH, Hassan M, Morad N (2011). Light and electron microscopic study of the toxic effect of prolonged lead exposure on the seminiferous tubules of albino rats and the possible protective effect of ascorbic acid. Food and Chemical Toxicol 49:734-743.

Evans G, Maxwell WMC. Handling and examination of semen (1987). In: Maxwell WMC,editor. Salamon's artificial insemination of sheep and goats. Sydney. Australia. Butterworths. p. 93.

Gabuchyan VV (1987). Impaired mechanism of the reproductive function in copper chloride exposed white male rats. Gig Tr Prof Zabol 9:28-31.

Garcia-Lestòn J, Méndez J, Pásaro E, Laffon B (2010). Genotoxic effects of lead: An updated review. Environment International 36:623-636.

Hassan NHA, Fahmy MA, El Dawy HA (1985). Effects of malathion and sevin on spermatocyte chromosomes and sperm morphology of mice. Egypt J Med sci 16(1):95-104.

Hsu PC, Liu M Y, Hsu CC, Chen LY, Guo YL (1998). Effects of vitamin $\mathrm{E} /$ or $\mathrm{C}$ on reactive oxygen species related lead toxicity in the rat sperm. Toxicology 128:169-179.

IARC (International Agency for Research on Cancer) (1987). Lead and compounds, inorganic. Vol 23 (Suppl.7). IARC Monographs. Lyon.

IARC (International Agency for Research on Cancer) (2006). 
418

Inorganic and organic lead compounds. IARC Monographs on the Evaluation on carcinogenic Riscks to Humans. Lyon; IARC.

Janisch KM, Milde J, Schempp H, Elstner EF (2005). Vitamin C, vitamin E and flavonoids. Dev Dphthalmo 38:59-69.

Johansson L, Pellicciari CE (1988). Lead-induced changes in the stabilization of the mouse sperm chromatin. Toxicol 51: 11-24.

Kaczmarski F (1974). Motor end-plates in the extraocular muscles of small mammals. Acta Anat Basel 89 (3):372-386.

Lancranjan I, Popescu HI, Avanescu O, Klepsch I, Serbanescu M (1975). Reproductive ability of workmen occupationally exposed to lead. Arch Environ Health 30:396-401.

Lavu S, Reddy PP, Reddi OS (1985). Iodine-125 induced micronuclei and sperm head abnormalities in mice. Stud Phys Chem Med 47(3):49-53.

Madhavi D, Rudrama K, Devi K, Kesava Rao, Reddy PP (2007). Modulating effect of Phyllanthus fruit extract against lead genotoxicity in germ cells of mice. J. Enviro Biol 28:115117.

Matousek J, Petrovská E (1969). Antifertilizing effect of the seminal vesicle fluid of bulls on females. J. Reprod Fert 20: 189.

Moore CR, Price D, Gallagher TF (1930a). Rat - Prostate cytology as a testis - hormone indicator and the prevention of castration changes by testis-extract injections. America Journal of Anatomy 45:71-107.

Mukherjee A, Giri AK, Sharma A, Talukder G (1988). Relative efficacy of short-term tests in detecting genotoxic effects of cadmium chloride in mice in vivo. Mutation Res p. 206 285.

Murugesan P, Muthusamy T, Balasubramanian K, Arunakaran $\mathrm{J}$ (2007). Effects of vitamins $\mathrm{C}$ and $\mathrm{E}$ on steroidogenic enzymes mRNA expression in polychlorinated biphenyl (Aroclor 1254) exposed adult rat Leydig cells. Toxicology 232: 170-182.

Muthu K, Krishnamoorthy P (2012). Effect of Vitamin C and Vitamin E on Mercuric Chloride -Induced Reproductive Toxicity in Male Rats. Muthu and Krishnamoorthy Biochem Pharmacol 1:7.

Nabil MI, Esam AE, Hossam SE, Yasmine EAM (2012). Effect of lead acetate toxicity on experimental male albinos rat. Asian Pacific J Tropical Biomedecine 41-46.

Nava-Hernandez MP, Hauad-Marroquin LA, Bassol-Mayagoitia S, Garcia-Arenas G, Mercado-Hernandez R, EchavarriGuzman MA, Cerda-Flores RM (2009). Lead-, cadmium-, and arsenic-induced DNA damage in rat germinal cells. DNA Cell Biol 28:241-248.

Nordenson I, Beckman G, Beckman L, Nordstrom S (1978). Occupational and environmental risks in and around a smelter in northern Sweden: II. Chromosomal aberrations in workers exposed to arsenic. Hereditas 88:47-50.

Pomerol J M, Arrondo JL (1004). Practica Andrologica Barce- lona Masson-Salvat.

Preston RJ, Dean BJ, Galloways S, Hoden H, McFee A.F, Shelby M (1987). Mammalian in vivo cytogenetic assays: Analysis of chromosome aberration in bone marrow cells. Mutat Res 189:157-165.

Ploetz R, Heine G, Haynes J, Watson M (2002). An investigation of biological attributes that may contribute to the importance of Phytophthora capsici as a vegetable pathogen in Florida. Ann Appl Biol 140:61-67

Sánchez-Gutiérrez M, García-Montalvo E, Izquierdo-Vega J, Del Razo L (2008). Effect ofdietary selenium deficiency on the in vitro fertilizing ability of mice spermatozoa. Cell Biol Toxicol 24:321-9.

Shi L, Zhang C, Yue W, Shi L, Zhu X, Lei F (2010). Short-term effect of dietary seleniumenriched yeast on semen parameters, antioxidant status and Se concentrationin goat seminal plasma. Anim Feed Sci Technol 157:104-8.

Soheir M, El Nahas HA, Halima Abdou (1989). Chromosome aberrations in spermatogonia and sperm abnormalities in Curacron-treated mice. Mutation Research Genetic Toxicology $222(4): 409-414$.

Sokol RZ (1987). Hormonal effects of lead acetate in the male rat. Mechanism of action. Biol Reprod 37:1135-1138.

Sönmez M, Türk G, Yüce A (2005). The effect of ascorbic acid supplementation on sperm quality, lipid peroxidation and testosterone levels of Wistar rats. Theriogenology 63:206372.

Topham JC (1980a). The detection of carcinogen-induced sperm head abnormalities in mice. Mutation Res 69:149155.

Tsuji LJS, Karagatzides (2001). Chronic lead exposure, body condition and testis mass in Wild Mallard ducks. Bull Environ Contam Toxicol 67:489-495.

Uzun FG, Kalender S, Durak D, Demir F, Kalender Y (2009). Malathion-induced testicular toxicity in male rats and the protective effect of vitamins $\mathrm{C}$ and $\mathrm{E}$. Food and Chemical Toxicology 47:1903-1908.

Wang B J, Lien YH, Yu ZR (2004). Supercritical fluid extractive fractionation: study of the antioxidant activities of propolis. Food Chem 86:237-243.

Wilson MJ, Kaye D, Edward SW, Quach HT, Sinha AA, Vatassery GT (2003). Effect of Vitamin E deficiency on the growth and secretory function of the rat prostatic complex. Exp Mol Pathol 74:267-275.

Winder C (1989). Reproductive and chromosomal effect of occupational exposure to lead on the male. Reprod Toxicol 3: 221-233.

Wise SS, Schuler JH, Holmes AL, Katsifis SP, Ketterer ME, Hartsock WJ (2004). Comparison to two particulate hexavalent chromium compouds: barium chromate is more genotoxic than lead chromate in human lung cells. Environ Mol Mutagen 44:156-62.

Wise SS, Schuler JH, Katsifis SP, Wise JP (2003). Barium chro- 
mate is cytotoxic and genotoxic to human lung cells. Environ Mol Mutagen 42: 274-278.

Wu ASH, Oldfield JE, Shull LR, Cheeke PR (1979). Specific effect of selenium deficiency onrat sperm. Biol Reprod 20: 793-8.

Wyrobek AJ, Bruce WR (1978). Induction of sperm shape abnormalities in mice and humans. In: Hollaender A, editor. Chemical Mutagens: principles and Methods for their detection. Vol. 5. New York: Plenum Press. p. 257-285.
Xie H, Wise SS, Holmes AL, Xu B, Akeman TP, Pelsue SC (2005). Carcinogenic lead chromate induce DNA doublestrand breaks in human lung cells. Mutat Res 586:160-172.

Youssef MI (2010). Vitamin E modulates reproductive toxicity of pyrethroid lambda-cyhalothrin in male rabbits. Food and Chemical Toxicology 48 (5):1152-1159.

Yue DB, Yan LY, Luo HL, Jin XX, Xu X (2010). Effect of Vitamin E supplementation on semen quality and the testicular cell membranal and mitochondrial antioxidant abilities in Aohan fine-wool sheep. Anim Reprod Sci 118:217-222. 